\title{
Identification and characterization of a putative serine protease expressed in vivo by Mycobacterium avium subsp. paratuberculosis
}

\author{
Rona M. Cameron, ${ }^{1}$ Karen Stevenson, ${ }^{1}$ Neil F. Inglis, ${ }^{1}$ Joan Klausen ${ }^{2}$ \\ and J. Michael Sharp'
}

Author for correspondence: J. Michael Sharp. Tel: +44 31664 3262. Fax: +44 316648001.

\footnotetext{
1 Moredun Research Institute, 408 Gilmerton Road, Edinburgh EH17 7JH, UK

2 National Veterinary Laboratory, Copenhagen, Denmark
}

\begin{abstract}
A putative serine protease expressed in vivo by Mycobacterium avium subsp. paratuberculosis was isolated from a lambda gt11 genomic expression library by screening with serum from a naturally infected sheep. The gene was contained in two overlapping clones, which were shown by antibody elution to encode a protein of $34 \mathrm{kDa}$ in $M$. a. paratuberculosis. The clones were sequenced and database searches detected a motif identical to the active serine site in trypsin, and $30 \%$ homology to the putative serine proteases (HtrA proteins) of Escherichia coli, Salmonella typhimurium, Brucella abortus and Rochalimaea henselae.
\end{abstract}

Keywords: Mycobacterium avium, paratuberculosis, serine protease, $34 \mathrm{kDa}$ antigen, $\mathrm{Htr} \mathrm{A}$

\section{INTRODUCTION}

Paratuberculosis (syn. Johne's disease) is a chronic granulomatous enteritis of ruminants caused by $M y c o-$ bacterium avium subsp. paratuberculosis and, occasionally, by $M$. avium subsp. silvaticum (Chiodini et al., 1984; Matthews \& McDiarmid, 1979). The outcome of infection of the host is variable, ranging from complete recovery in the majority, to clinical disease in a small proportion. The interaction between host and bacterium is poorly understood due, in part, to inadequate knowledge of the properties of these mycobacteria. Consequently, we have focussed our interest on $M$. a. paratuberculosis genes and gene products that are involved in the bacterium-host interaction, particularly those proteins which are immunogenic in the natural ruminant host, and which may be involved in pathogenesis.

Individual proteins have been identified in several mycobacteria by producing monoclonal antibodies (mAbs) (Engers et al., 1985; Kolk et al., 1989), and using these to screen genomic expression libraries (Young et al., 1985; Morris et al., 1988, 1990; Rouse et al., 1991). However, this approach has identified principally heat shock proteins (Husson \& Young, 1987; Lu et al., 1987; Young \& Mehlert, 1989), as the use of mycobacterial lysates in immunization procedures does not reflect accurately the immune response of the natural host to infection. To

\footnotetext{
Abbreviation: mAb, monoclonal antibody.
}

The EMBL accession number for the sequence reported in this paper is Z23092. circumvent this problem, we chose to construct an $M$. a. paratuberculosis genomic expression library and screen with serum from a naturally infected animal. By utilizing the natural immune response of the infected host to $M$. $a$. paratuberculosis we aimed to detect antigens expressed in vivo that may be absent from, or very poorly expressed in, bacteria grown in vitro, suggesting a possible involvement in pathogenesis (Donachie \& Gilmour, 1988; Jonson et al., 1989). A similar approach in which $M$. leprae lambda gt11 genomic libraries were screened with pooled sera from leprosy patients, resulted in the identification of several new proteins which were not detected by mouse monoclonal antibodies or rabbit hyper-immune serum (Clark-Curtiss et al., 1990; Sathish et al., 1990; Wieles et al., 1994). The present report describes the characterization of two overlapping clones isolated from an $M$. $a$. paratuberculosis lambda gt11 library, which were found to encode a putative serine protease.

\section{METHODS}

Bacterial strains, bacteriophages, plasmids and growth conditions. Strain JD88/107 of $M$. a. paratuberculosis, used throughout the experiments, was isolated from a commercially farmed red deer (Cervus elapbus) and propagated on Stuart's medium (Stuart, 1965) supplemented with mycobactin J. Escherichia coli strains NM522, JM101, Y1088 and Y1089 were grown in Luria-Bertani (LB) medium or LB solidified with $1.5 \%(w / v)$ agar (Sambrook et al., 1989). Lambda recombinant phages were propagated as described by Sambrook et al. (1989). Expression plasmid pMS1S (Scherf et al., 1990) was kindly supplied by M. Schreiber and J. Scaife. Plasmids pUC8 and 
pUC18 (Yanisch-Perron et al., 1985) were purchased from Life 'Technologies.

Library construction and screening. Two hundred milligrams (wet wt) of $M$. a. paratuberculosis cells were lysed in $4 \mathrm{M}$ guanidine isothiocyanate using an Eaton press (Eaton, 1962). DNA was purified using standard laboratory procedures (Sambrook et al., 1989). The lambda gt11 library was constructed as described by Young et al. (1985) using EcoRI-cleaved lambda gt11 DNA and Gigapack II Gold packaging extracts from Stratagene. Amplification was performed using E. coli Y1088.

The library was screened with antiserum from a sheep with Johne's disease (JD87/40) using the procedure described by Young et al. (1985) with a few modifications. Nitrocellulose filters were incubated with the recombinant phage overnight at $37^{\circ} \mathrm{C}$ and were blocked in $50 \mathrm{mM}$ Tris pH 7, $150 \mathrm{mM} \mathrm{NaCl}$, $0.05 \%(\mathrm{v} / \mathrm{v})$ Tween 20,50\% (v/v) horse serum for $2 \mathrm{~h}$. Antibody was absorbed with $1 \mathrm{ml}$ of a concentrated lysate of induced E. coli Y1090 cells. Bound antibody was detected using horseradish peroxidase-conjugated donkey-anti sheep IgG.

DNA manipulations and sequencing. Recombinant phage DNA was prepared from plate lysates and subsequent subcloning into the plasmid vectors $\mathrm{pUC8}, \mathrm{pUC18}$ and $\mathrm{pMS1S}$ was carried out using standard procedures described by Sambrook $e t$ al. (1989). Subcloning from lambda gt11 to pMS1S conserved the open reading frame and allowed expression of the recombinant protein. Plasmid DNA was prepared using the alkaline lysis procedure and purified by equilibrium centrifugation in caesium chloride-ethidium bromide gradients (Sambrook $e t$ al., 1989). Both strands of DNA from the S4 and S8 plasmid clones were sequenced by the dideoxy chain termination method (Sanger et al., 1977) using Sequenase version 2.0 (United States Biochemicals), the M13 universal primer, a pMS1S specific primer (ACGTACGGTACCAAGCT), and a series of internal 17-mer oligonucleotides. The sequencing procedure used was that recommended by USB. dCTP labelling mix and $\left[{ }^{35} \mathrm{~S}\right]-$ $\mathrm{dC} T \mathrm{P} \alpha \mathrm{S}$ were used to achieve better incorporation into the $\mathrm{C}-\mathrm{C}$ rich mycobacterial DNA. The Sequenase enzyme was diluted $1: 4$. Reactions were run on $40 \%(\mathrm{v} / \mathrm{v})$ formamide, $7 \mathrm{M}$ urea, $8 \%(\mathrm{w} / \mathrm{v})$ acrylamide gels in 'glycerol-tolerant' sequencing buffer (1.78 M Tris, $0.57 \mathrm{M}$ taurine, 0.01 M EDTA) to eliminate compressions, as recommended by USB.

Purification of recombinant fusion protein. A culture of $E$. roli NM522 containing the pMS1S/S4 or pMS1S/S8 plasmid was grown to an $\mathrm{OD}_{600}$ of 0.5 , and induced with $10 \mathrm{mM}$ IPTG. After a further $4 \mathrm{~h}$ growth, cells were pelleted, resuspended in $10 \mathrm{ml} 2 \mathrm{mM}$ PMSF and lysed in a mini French pressure cell at 1500 p.s.i. $(10.35 \mathrm{MPa})$. The lysate was clarified by centrifugation at $100000 \mathrm{~g}$ and adjusted to $300 \mathrm{mM} \mathrm{NaCl}, 50 \mathrm{mM}$ Tris $/ \mathrm{HCl} \mathrm{pH} 8$. Recombinant fusion protein was purified using a $2 \mathrm{ml}$ column of aminobenzyl thiogalactopy ranoside (ABTG) agarose (Sigma). The column was washed with $10 \mathrm{ml} 300 \mathrm{mM}$ $\mathrm{NaCl}, 50 \mathrm{mM}$ Tris $/ \mathrm{HCl} \mathrm{pH} 8,5 \mathrm{ml} 600 \mathrm{mM} \mathrm{NaCl}, 50 \mathrm{mM}$ Tris/ $\mathrm{HCl} \mathrm{pH} 8$ and $10 \mathrm{ml} 50 \mathrm{mM}$ Tris $/ \mathrm{HCl} \mathrm{pH} 8$ and the fusion protein eluted with $10 \mathrm{ml} 0 \cdot 1 \mathrm{M}$ borate $\mathrm{pH} 10$. The eluate was collected on ice into $1 \mathrm{ml}$ of $2 \mathrm{M}$ Tris/ $\mathrm{HCl} \mathrm{pH} 7$, dialysed overnight against $10 \mathrm{mM}$ Tris $/ \mathrm{HCl} \mathrm{pH} 8$, and concentrated to 2-3 ml with PEG 20000 (Sigma). Total protein concentration was estimated with the Pierce BCA micro protein assay as recommended by the manufacturer.

SDSPAGE. Protein samples were boiled for $90 \mathrm{~s}$ in an equal volume of $2 \times$ Laemmli sample buffer $[250 \mathrm{mM}$ Tris $/ \mathrm{HCl}$ $\mathrm{pH} 6.8,2 \%(\mathrm{w} / \mathrm{v})$ SDS, $4 \%(\mathrm{v} / \mathrm{v}) 2$-mercaptoethanol, $20 \%$ $(\mathrm{w} / \mathrm{v})$ sucrose, $0.002 \%(\mathrm{w} / \mathrm{v})$ bromophenol blue] and separated on a discontinuous SDS-polyacrylamide gel [3\% (w/v) stacking gel, $10 \%$ resolving gel] using the buffering system of Laemmli
(1970). Molecular mass standards (BDH Electran; $12-78 \mathrm{kDa}$ ) were run on each gel.

Western blotting. Proteins were transferred from SDS-polyacrylamide gels onto nitrocellulose by electroblotting in Tris/ glycine blot buffer [20 mM Tris, $153 \mathrm{mM}$ glycine, $20 \%$ (v/v) methanol, $\mathrm{pH} \mathrm{8.3]}$ at $100 \mathrm{~V}$ for $1 \mathrm{~h}$. After blotting, the membranes were stained with Ponceau S (Sigma) for 5 min to confirm transfer, and washed for $30 \mathrm{~min}$ in PBS containing $0.5 \%(\mathrm{v} / \mathrm{v})$ Tween 20, $1 \mathrm{mM}$ EDTA, $350 \mathrm{mM} \mathrm{NaCl}, \mathrm{pH} 7 \cdot 2$ (PBS-Tween). Membranes were probed for $1 \mathrm{~h}$ at room temperature with either clinical sheep serum (absorbed with lysed E. coli NM522) diluted 1:40 in PBS-Tween, specifically eluted clinical sheep antibodies, or mAb 5.8 (neat tissue culture supernate) raised against S4 fusion protein. Membranes were washed and incubated for $1 \mathrm{~h}$ at room temperature in horseradish peroxidase-conjugated swine anti-sheep $\operatorname{IgG}$, or rabbit anti-mouse IgG (Dako) diluted 1:2000 in PBS-Tween. Bands were developed with $0.1 \mathrm{M}$ Tris $/ \mathrm{HCl} \mathrm{pH} \mathrm{7.5,0.15 \% (v/v)}$ $\mathrm{H}_{2} \mathrm{O}_{2}, 0 \cdot 2 \%$ (w/v) diaminobenzidine.

Antibody elution studies were performed as described by Beall \& Mitchell (1986).

Monoclonal antibody production. Purified pMS1S/S4 fusion protein solubilized in $10 \mathrm{mM}$ Tris $/ \mathrm{HCl} \mathrm{pH} 8$ was inoculated intraperitoneally into 8-10 week old $\mathrm{Balb} / \mathrm{c}$ mice three times over two week intervals. The mice were finally boosted $3 \mathrm{~d}$ before fusion with the myeloma cell line P3 X63 Ag.8.6.5.3 using standard procedures (Goding, 1980).

Hybridoma culture supernates were screened in ELISAs in microtitre plates coated with either $\mathrm{S} 4$ fusion protein or $\beta$ galactosidase. Clones reacting with $\mathrm{S} 4$ fusion protein but not $\beta$-galactosidase were selected.

Two Balb/c mice were inoculated intraperitoneally with $5 \times 10^{6}$ hybridoma cells, and the resulting ascitic fluid was collected after $14 \mathrm{~d}$. IgG1 was purified from the ascites on a protein ASepharose column (Pharmacia), and coupled to cyanogen bromide-activated Sepharose (Pharmacia) as recommended by the manufacturer. The column was then equilibrated in PBS supplemented with $0.5 \mathrm{M} \mathrm{NaCl}$.

Purification of $34 \mathrm{kDa}$ protein from $\boldsymbol{M}$. a. paratuberculosis. One gram (wet wt) of M. a. paratuberculosis cells was resuspended in $5 \mathrm{ml}$ of PBS supplemented with $0.5 \mathrm{M} \mathrm{NaCl}$, and lysed in an Eaton Press. After sonication to shear DNA, the lysate was mixed with the monoclonal affinity column matrix overnight at $4{ }^{\circ} \mathrm{C}$. The column was then washed with $20 \mathrm{ml}$ PBS supplemented with $0.5 \mathrm{M} \mathrm{NaCl}$ and the protein eluted with $10 \mathrm{ml}$ of $0 \cdot 1 \mathrm{M}$ glycine $\mathrm{pH} 2 \cdot 3$. The eluate was then dialysed against $10 \mathrm{mM}$ Tris $\mathrm{pH} 8$, concentrated to $2-3 \mathrm{ml}$ with PEG 20000 (Sigma) and further to $500-1000 \mu \mathrm{l}$ with a Millipore Ultrafree microconcentrator (10 kDa cutoff).

$\mathbf{N}$-terminal sequencing. Approximately $2 \mu \mathrm{g}$ of purified $M$. $a$. paratuberculosis $34 \mathrm{kDa}$ protein was run on SDS-PAGE, and Western blotted onto PVDF (polyvinylidene difluoride) membrane using borate blot buffer [ $50 \mathrm{mM}$ sodium borate $\mathrm{pH} 8$, $20 \%(\mathrm{v} / \mathrm{v})$ methanol, $0.02 \%(\mathrm{v} / \mathrm{v})$ mercaptoethanol]. The blot was stained with Coomassie blue, and the bands excised. The first 20 amino acids were sequenced from this membrane by Edman degradation at the microchemical facility, IAPGR, Babraham, Cambridge, UK.

\section{RESULTS}

\section{Library screening}

The genomic library of $M$. a. paratuberculosis (strain JD88/107) constructed in bacteriophage lambda gt11 was shown to contain $8 \times 10^{5}$ individual phage. Subsequent 


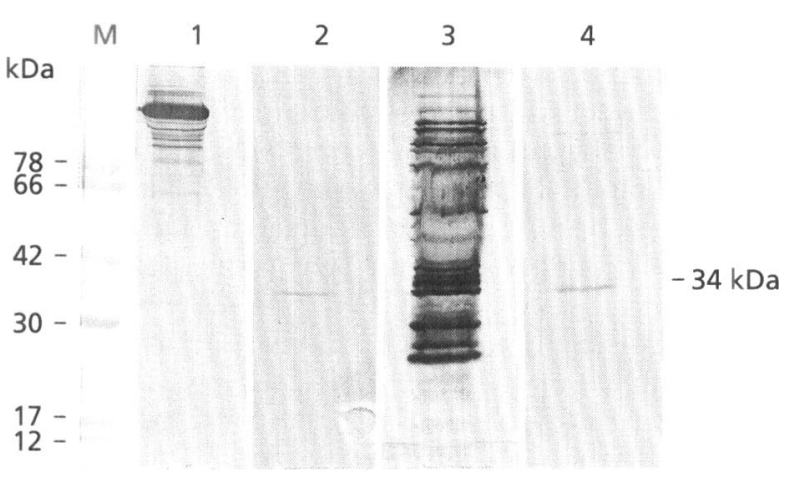

Fig. 1. Western blot demonstrating relationship between $\$ 4$ fusion protein and a $34 \mathrm{kDa}$ protein in $M$. a. paratuberculosis. Lane 1, pMS1S/S4 fusion protein probed with sheep serum JD87/39; lane 2, M. a. paratuberculosis lysate probed with JD87/39 antibody eluted from pMS1S/S4 fusion protein; lane 3, $M$. a. paratuberculosis lysate probed with sheep serum JD87/39; lane $4, M$. a. paratuberculosis lysate probed with mAb 5.8 raised against pMS1S/S4 fusion protein. M, Molecular mass markers stained with Ponceau S (Sigma).

amplification in E. coli $\mathrm{Y} 1088$ yielded a plate stock of $10^{9}$ p.f.u. $\mathrm{ml}^{-1}$. The amplified library contained $65 \%$ recombinants with an average insert size of $4 \mathrm{~kb}$. Statistical analysis showed this library to be representative of the M. a. paratuberculosis genome (Old \& Primrose, 1989).

Approximately 125000 plaques were screened with antiserum JD87/40 obtained from a sheep with naturally acquired Johne's disease and eight recombinant clones, designated S1 to S8, were isolated. The DNA inserts from two of these recombinant phage (S4 and S8) were subcloned into the plasmid vector pMS1S and the encoded antigens expressed in $E$. coli as $\beta$-galactosidase fusion proteins.

Due to the random generation of DNA fragments during library construction, recombinant clones often contain only part of an open reading frame (ORF) and, consequently, express only a part of the bacterial antigen. Therefore, the size of the $M$. a. paratuberculosis protein encoded by the clones was determined by an antibody elution procedure. Western blots of S4 and S8 fusion proteins were incubated with serum from a sheep (JD87/39) with clinical paratuberculosis that had been shown previously to recognize both clones. Specific antibody bound by the fusion proteins was eluted and used to probe a Western blot of M. a. paratuberculosis lysate (Fig. 1). Antibodies eluted from both S4 and S8 fusion proteins detected a $34 \mathrm{kDa}$ protein in M. a. paratuberculosis, and also recognized the reciprocal fusion protein after absorbing with $\beta$-galactosidase.

\section{Sequencing of DNA inserts}

DNA sequencing revealed that both the S4 and S8 clones contained the same $\mathrm{C}$-terminal portion of a gene encoding a predicted protein of 210 amino acids. The S8 clone also contained a further $480 \mathrm{bp}$ upstream of this region, and was thought to represent the complete gene. This contained a possible Shine-Dalgarno sequence (AGGA-

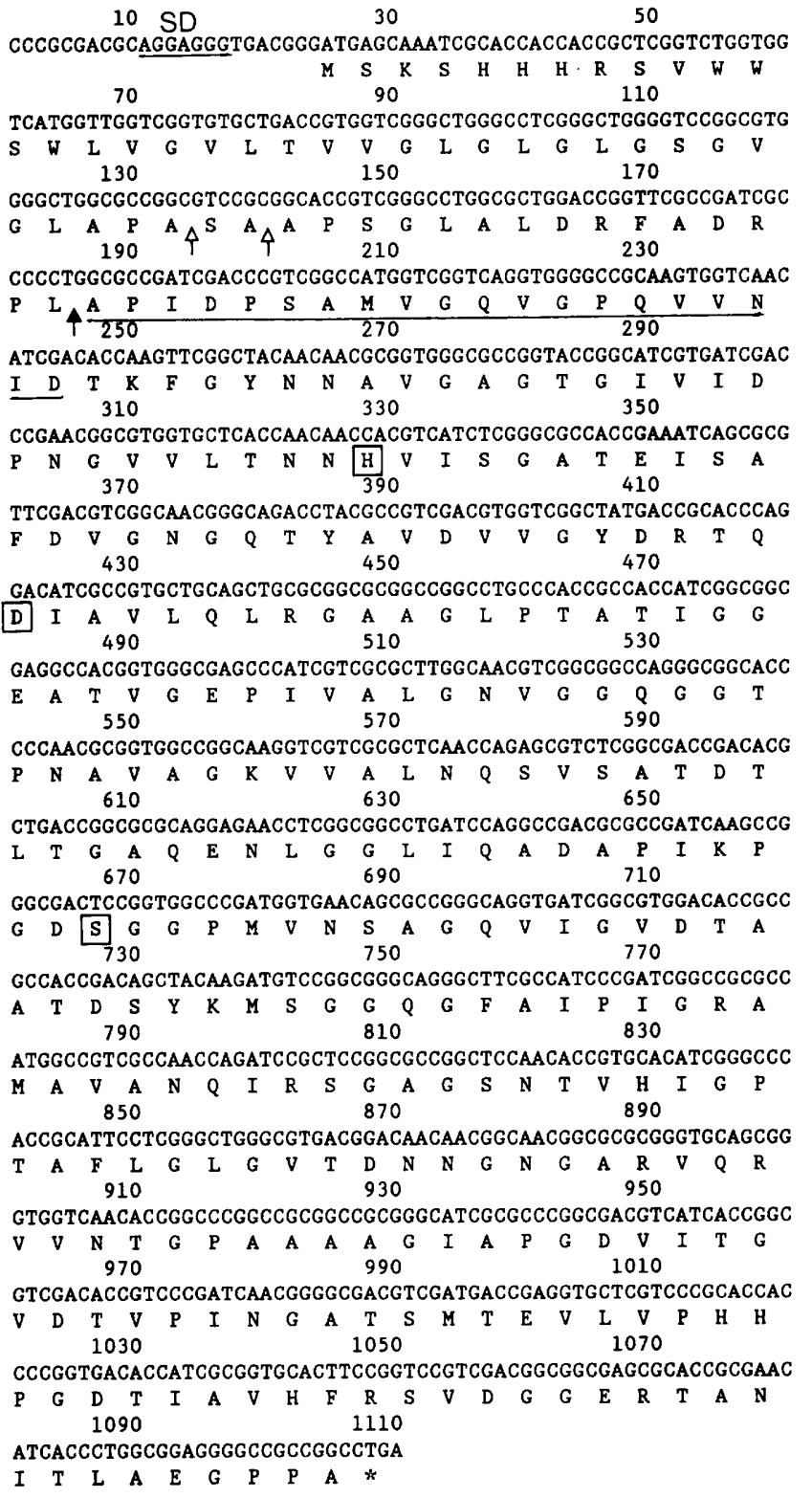

Fig. 2. Nucleotide sequence of the DNA inserts of clones $S 4$ and S8, encoding the $34 \mathrm{kDa}$ protein of $M$. a. paratuberculosis. The deduced amino acid sequence is shown in single-letter code. The putative Shine-Dalgarno sequence (SD) is underlined. The $\mathrm{N}$-terminus of the native protein is marked by $\uparrow$ and underlined. Possible signal cleavage sites after amino acids 37 and 39 marked by $\uparrow$. The histidine, aspartate and serine residues homologous to those in the HtrA proteins are boxed. This sequence has been assigned the EMBL accession number Z23092.

GGG) and start codon (ATG) preceding a single ORF of $1083 \mathrm{bp}$ encoding a predicted protein of 361 amino acids (Fig. 2). The first 40 amino acids of this sequence were highly hydrophobic, suggesting the protein may contain a leader or signal sequence which is removed after translation.

Database searches using the complete deduced amino acid sequence were run on SEQNET at the SERC Daresbury 
computing facility. A SWEEP search (Akrigg et al., 1988) of the OWL protein database (Bleasby \& Wootton, 1990) identified four bacterial proteins, the HtrA proteins of $E$. coli (Lipinska et al., 1988), Salmonella typhimurium (Johnson et al., 1991), Brucella abortus (Roop et al., accession no. L09274) and Rocbalimaea benselae (Anderson et al., accession no. L20127), which displayed $30 \%$ homology to the probe sequence. A MOTIFS search using the PROSITE dictionary (Bairoch, 1991) detected a motif ' GDSGG' at amino acid position 213-217, which showed $100 \%$ homology to the residues surrounding the active serine in a trypsin-like serine protease.

\section{Purification of native protein}

The native $34 \mathrm{kDa}$ protein identified by antibody elution was purified from lysates of $M . a$. paratuberculosis on an affinity column that was prepared using a monoclonal antibody ( $\mathrm{mAb} 5.8$ ) raised against $\mathrm{S} 4$ fusion protein. This monoclonal antibody also recognized the $34 \mathrm{kDa}$ protein on Western blots of M. a. paratuberculosis (Fig. 1). Both eluted antibody and $\mathrm{mAb} 5.8$ detected a second band of $90-100 \mathrm{kDa}$ on Western blots of $M$. a. paratuberculosis lysate (Fig. 1). This $90-100 \mathrm{kDa}$ protein is unlikely to be a dimer/trimer, due to the reducing conditions of the gel; and other studies (unpublished results) suggest that the reaction is due to a cross-reactive epitope. Approximately $40 \mu \mathrm{g}$ of pure $34 \mathrm{kDa}$ protein was recovered from $1 \mathrm{~g}$ (wet wt) of M. a. paratuberculosis. The N-terminal sequence of this protein was derived by Edman degradation, and was found to be identical to amino acids $55-74$ of the S8 deduced protein sequence (Fig. 2).

\section{DISCUSSION}

This paper describes the identification and characterization of a putative serine protease expressed in vivo by $M . a$. paratuberculosis. The protein was encoded by two overlapping clones, which were extracted from a lambda gc11 genomic expression library of $M$. a. paratuberculosis by screening with serum from a naturally infected sheep. The isolated clones therefore were known to encode a mycobacterial protein expressed in vivo which was also involved in the ovine immune response to infection with M. a. paratuberculosis.

Genes encoding $34 \mathrm{kDa}$ proteins have been described in both M. a. paratuberculosis (De Kesel et al., 1993) and $M$. tuberculosis (Barnini et al., EMBL accession no. X69463). Comparison of the previously described $M$. a. paratuberculosis $34 \mathrm{kDa}$ protein with $\mathrm{S} 4$ and $\mathrm{S} 8$ fusion proteins by reciprocal reactions with polyclonal antisera and monoclonal antibodies failed to demonstrate any relationship between them (unpublished results). This lack of homology has been confirmed further by the absence of any homology between the recently published genomic sequence (Gilot et al., 1993) and that obtained from S8. Similarly, no homology was detected between the S8 clone and the nucleotide sequence of the $M$. tuberculosis $34 \mathrm{kDa}$ protein. The gene contained in the S8 clone therefore has not been described previously in any of the Mycobacteriaceae.
The deduced amino acid sequence of the $\mathrm{S} 8$ clone contains a highly hydrophobic $\mathrm{N}$-terminus. This is characteristic of a signal peptide, and two possible signal cleavage sites of Ala-X-Ala are situated at positions 35-37 and 37-39 in the protein. The first of these, $\mathrm{Ala}^{35}-\mathrm{Pro}^{36}-\mathrm{Ala}^{37}$, can be dismissed, as proline is a 'forbidden' residue and cannot be part of a signal cleavage site (von Heijne, 1984). Cleavage after $\mathrm{Ala}^{37}-\mathrm{Ser}^{38}-\mathrm{Ala}^{39}$ is more likely, but leaves a sequence of 15 amino acids between the cleavage site and the $\mathrm{N}$-terminus of the protein as determined by Edman degradation. It is doubtful that the entire peptide of 54 amino acids would be cleaved after $\mathrm{Arg}^{52}-\mathrm{Pro}^{53}-\mathrm{Leu}^{54}$, as these residues will not be recognized by a signal peptidase (von Heijne, 1984). The 15 amino acid sequence may have been removed during purification of the native protein, as elution was performed in $0.1 \mathrm{M}$ glycine $\mathrm{pH} 2 \cdot 3$, which may have resulted in hydrolysis of the protein before dialysis against Tris $\mathrm{pH} 8$. However, it is also possible that the protein contains a pro-peptide of 15 amino acids which, although shorter, is similar to that observed with the alpha-lytic serine protease of Lysobacter enzymogenes (Epstein \& Wensink, 1988). Both the signal peptide of 39 amino acids and the pro-peptide of 15 amino acids would then be removed during post-translational modification and possible secretion of the protein.

Database searches have shown the $\mathrm{S} 8$ protein to resemble most closely a trypsin-like serine protease. This class of protease has been well characterized in eukaryotes, and Xray crystallography has revealed the active site to be comprised not only of serine, but also of histidine and aspartate, due to the three dimensional structure of the molecule. The classical trypsin active site triad is $\mathrm{His}^{57}$ Asp $^{102}$ Ser $^{195}$, and any protein matching this pattern may be regarded as a potential serine protease (Neurath, 1989; Dunn, 1989). Although the S8 protein contains a motif that completely matches the trypsin serine active site (amino acid position 215), no corresponding histidine and aspartate residues occur at positions 77 and 122 . The absence of any significant homology with trypsin, excluding the serine active site, suggests the $\mathrm{S} 8$ protein is not a form of trypsin. However, other serine proteases such as subtilisin maintain the His-Asp-Ser components of the active site, despite differing from trypsin in both amino acid composition and tertiary structure (Neurath, 1989). Thus the active serine in the conserved motif in the S8 protein may combine with a histidine and aspartate residue elsewhere in the sequence to form the electrostatically important active site.

Further evidence for the $\mathrm{S} 8$ protein being a serine protease was provided by homology with four possible bacterial serine proteases: the HtrA proteins of E. coli (Lipinska $e t$ al., 1988), S. typhimurium (Johnson et al., 1991), Br. abortus (Roop et al., OWL accession no. L09274), and R. benselae (Anderson et al., OWL accession no. L20127). As these proteins have been described only recently, there are as yet no X-ray crystallographic data, and their active sites are not well defined. However, an endopeptidase activity of the E. coli HtrA has been reported recently (Lipinska $e t$ al., 1990). Although only $30 \%$ homology exists between the entire S8 protein and these four bacterial proteases, a 


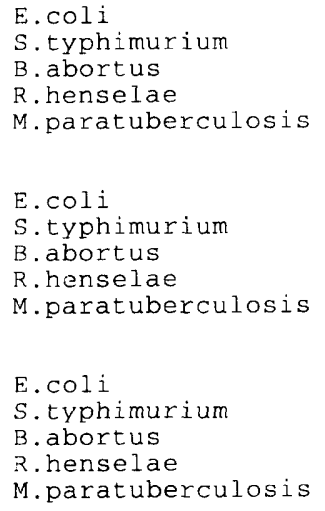

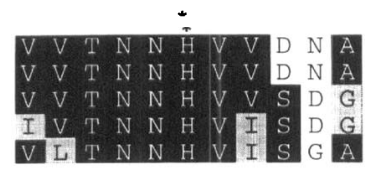
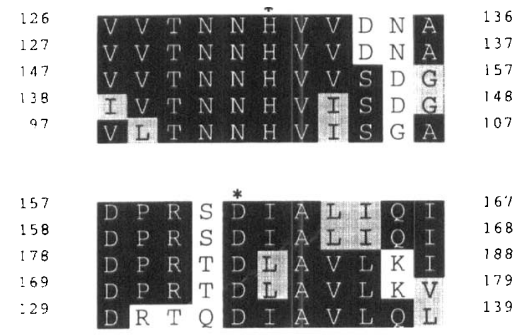

231
232
152
242
210

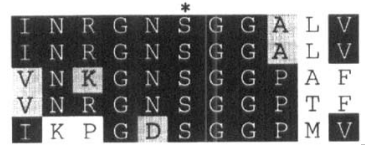

Fig. 3. Partial homology of the deduced amino acid sequences of the $\$ 8$ protein and the HtrA proteins of Escherichia coli, Salmonella typhimurium, Brucella abortus and Rochalimaea henselae. Black boxing indicates complete identity; shaded boxing represents conserved amino acids. Active histidine, aspartate and serine are marked 米.

higher degree of homology (50-80\%) is observed at three sites,. containing histidine, aspartate and serine respectively (Fig. 3). The high conservation of amino acids at these three sites suggests that they probably represent the three important active residues which are brought together to form the active site of the protease.

The native $34 \mathrm{kDa}$ protein is highly immunogenic in infected sheep, goats and deer. Western blots have shown the S4 recombinant fusion protein to be recognized strongly by serum from $8 / 14(57 \%)$ sheep, $2 / 2$ goats, and $3 / 3$ deer with clinical Johne's disease. The other six sheep reacted weakly (unpublished results). Although this protein appears to be important in the immune response to $M$. a. paratuberculosis infection, only $40-50 \mu \mathrm{g}$ is recovered from $1 \mathrm{~g}$ of $M$. a. paratuberculosis cells grown in vitro. The HtrA proteins of E. coli and S. typhimurium have been shown to be stress proteins (Lipinska et al., 1989; Johnson et al., 1991), induced by heat shock and oxidative stress respectively. In vivo, mycobacteria undoubtedly are exposed to several types of stress during intracellular growth, and it is possible that, as with other HtrA proteins, levels of expression of the $34 \mathrm{kDa}$ protein may increase under these conditions. During less stressful growth in vitro the protein may be rapidly degraded intracellularly, or its expression accordingly down-regulated. This would account for the poor yield observed during the purification of the native protein from organisms grown in vitro.

Serine proteases have not been described previously in the Mycobacteriacae, and possible functions of the $34 \mathrm{kDa}$ protein are speculative. However, recent reports suggest that serine proteases are important components of the pathogenic mechanisms of other intracellular microorganisms. Plasmodium falciparum is thought to use a serine protease to gain entry into red blood cells during the blood-borne stage of malaria (Braun Breton \& Pereia da Silva, 1993). The P. falciparum gp76 and Plasmodium chabaudi gp68 appear to be serine proteases which specifically degrade the erythrocyte band 3 protein, thereby altering the erythrocyte cytoskeleton, and allowing entry of the parasite.

The HtrA serine protease of S. typhimurium also has been linked with virulence of the intracellular pathogen. Mutants with the transposon $\operatorname{Tn} p h o A$ inserted in the protease gene show a decreased ability to survive oxidative stress, similar to the killing mechanisms employed by macrophages (Johnson et al., 1991). This protein therefore may be important in allowing the organism to survive and replicate in this usually hostile environment.

M.a. paratuberculosis also is an intracellular pathogen, which persists and replicates in macrophages, and the mechanisms by which it evades killing within these cells are currently unknown. If, however, the native $34 \mathrm{kDa}$ protein uses the same physiological substrate as the $S$. typhimurium serine protease, the two proteins may perform a similar function that contributes to the intracellular survival of these pathogens.

\section{ACKNOWLEDGEMENTS}

The M. a. paratuberculosis strain used throughout this work was cultured by Kathleen Connor and John Porter at the Moredun Research Institute, Edinburgh. Statistical analysis was performed by Frank Wright, Scottish Agricultural Statistics Service, Edinburgh. This work was supported by grants from the Scottish Office, Agriculture and Fisheries Department, and the Commission of the European Communities (Competitiveness of Agriculture and Management of Agricultural Resources 8001-CT90-0014). Rona M. Cameron is the recipient of an Agricultural and Food Research Council PhD award.

\section{REFERENCES}

Akrigg, D., Bleasby, A. J., Dix, N. I. M., Findlay, J. B. C., North, A. C. T., Parry-Smith, D. J., Wootton, J. C., Blundell, T. L., Gardner, S. P., Hayes, F., Islam, S., Sternberg, M. J. E., Thornton, J. M., Tickle, I. J. \& Murray-Rust, P. (1988). A protein sequence/structure database. Nature 335, 745-746.

Bairoch, A. (1991). PROSITE: a dictionary of sites and patterns in proteins. Nucleic Acids Res 19, 2241-2245.

Beall, J. A. \& Mitchell, G. F. (1986). Identification of a particular antigen from a parasite cDNA library using antibodies affinity purified from selected portions of western blots. $J$ Immunol Methods 86, 217-223.

Bleasby, A. J. \& Wootton, J. C. (1990). Construction of validated, non-redundant composite protein sequence databases. Protein Eng 3, 153-159.

Braun Breton, C. \& Pereia da Silva, L. H. (1993). Malarial proteases and red blood cell invasion. Parasitol Today 9, 92-96.

Chiodini, R. J., Van Kruiningen, H. J. \& Merkal, R. S. (1984). 
Ruminant paratuberculosis (Johne's disease): the current status and future prospects. Cornell Vet 74, 218-262.

Clark-Curtiss, J. E., Thole, J. E. R., Sathish, M., Bosecker, B. A., Sela, S., de Carvalho, E. F. \& Esser, R. E. (1990). Protein antigens of Mycobacterium leprae. Res Microbiol 141, 859-871.

De Kesel, M., Gilot, P., Misonne, M. C., Coene, M. \& Cocito, C. (1993). Cloning and expression of portions of the 34-kilodalton protein gene of Mycobacterium paratuberculosis: its application to serological analysis of Johne's disease. J Clin Microbiol 31, 947-954.

Donachie, W. \& Gilmour, N. J. L. (1988). Sheep antibody response to cell wall antigens expressed in vivo by Pasteurella baemolytica serotype A2. FEMS Microbiol Lett 56, 271-276.

Dunn, B. M. (1989). Determination of protease mechanism. In Proteolytic Enzymes: a Practical Approach, pp. 57-81. Edited by R. J. Beynon \& J. S. Bond. Oxford: Oxford University Press.

Eaton, N. R. (1962). New press for disruption of microorganisras. $J$ Bacteriol 83, 1359-1360.

Engers, H. D., Bloom, B. R. \& Godal, T. (1985). Monoclonal antibodies against mycobacterial antigens. Immunol Today 6, 345, 347-348.

Epstein, D. M. \& Wensink, P. C. (1988). The $\alpha$-lytic protease gene of Lysobacter enzymogenes. J Biol Cbem 263, 16586-16590.

Gilot, P., De Kesel, M., Machtelinckx, L., Coene, M. \& Cocito, C. (1993). Isolation and sequencing of the gene coding for an antigenic 34-kilodalton protein of Mycobacterium paratuberculosis. J Bacieriol 175, 4930-4935.

Goding, J. W. (1980). Monoclonal Antibodies. Principle and Praitice. London: Academic Press.

von Heijne, G. (1984). How signal sequences maintain cleavage specificity. J Mol Biol 173, 243-251.

Husson, R. N. \& Young, R. A. (1987). Genes for the major protein antigens of Mycobacterium tuberculosis: the etiologic agents of tuberculosis and leprosy share an immunodominant antigen. Proc Natl Acad Sci US A 84, 1679-1683.

Johnson, K., Charles, I., Dougan, G., Pickard, D., O'Gaora, P., Costa, G., Ali, T., Miller, I. \& Hormaeche, C. (1991). The role of a stress response protein in Salmonella typhimurium virulence. Mol Microbiol 5, 401-407.

Jonson, G., Svennerholm, A.-M. \& Holmgren, J. (1989). V'ibrio cholerae expresses cell surface antigens during intestinal infection which are not expressed during in vitro culture. Infect Immun 57, $1809-1815$

Kolk, A. H. J., Evers, R., Groothuis, D. G., Gilis, H. \& Kuijper, S. (1989). Production and characterisation of monoclonal antibodies against specific serotypes of Mycobacterium avium and the Mycobacterium avium-Mycobacterium intracellulare-Mycobacterium scrofulaceum complex. Infect Immun 57, 2514-2521.

Laemmli, U. K. (1970). Cleavage of structural proteins during the assembly of the head of bacteriophage T4. Nature 227, 680-685.

Lipinska, B., Sharma, S. \& Georgopoulos, C. (1988). Sequence analysis and regulation of the HtrA gene of Escherichia coli: a $\sigma^{32}$ independent mechanism of heat-inducible transcription. Nucleic Acids Res 16, 10053-10067.

Lipinska, B., Fayet, O., Baird, L. \& Georgopoulos, C. (1989). Identification, characterisation and mapping of the Escherichia coli $b \operatorname{tr} A$ gene, whose product is essential for bacterial growth only at elevated temperatures. J Bacteriol 171, 1574-1584.

Lipinska, B., Zylicz, M. \& Georgopoulos, C. (1990). The HtrA (Deg P) protein, essential for Escherichia coli survival at high temperatures, is an endopeptidase. J Bacteriol 172, 1791-1797.
Lu, M. C., Lien, M. H., Becker, R. E., Heine, H. C., Buggs, A. M., Lipovesek, D., Gupta, R., Robbins, P. W., Grosskinsky, C. M., Hubbard, S. C. \& Young, R. A. (1987). Genes for immunodominant protein antigens are highly homologous in Mycobacterium tuberculosis, Mycobacterium africanum, and the vaccine strain Mycobacterium bovis BCG. Infect Immun 55, 2378-2382.

Matthews, P. R. J. \& McDiarmid, A. (1979). The production in bovine calves of a disease resembling paratuberculosis with a Mycobacterium sp. isolated from a wood pigeon (Columba palumbus L). Vet $\operatorname{Rec} 104,286$.

Morris, S. L., Rouse, D. A., Hussong, D. \& Chaparas, S. D. (1988). Isolation and characterisation of a recombinant $\lambda \mathrm{gt} 11$ bacteriophage which expresses an immunoreactive Mycobacterium intracellulare protein in Escherichia coli. Infect Immun 56, 3026-3031.

Morris, S. L., Rouse, D. A., Hussong, D. \& Chaparas, S. D. (1990). Isolation and characterisation of recombinant $\lambda \mathrm{gt} 11$ bacteriophages expressing four different Mycobacterium intracellulare antigens. Infect Immun 58, 17-20.

Neurath, H. (1989). The diversity of proteolytic enzymes. In Proteolytic Enzymes: a Practical Approach, pp. 1-13. Edited by R. J. Beynon \& J. S. Bond. Oxford: Oxford University Press.

Old, R. W. \& Primrose, S. B. (1989). In Principles of Gene Manipulation, chapter 7. Oxford: Blackwell Scientific Publications.

Rouse, D. A., Morris, S. L., Karpas, A. B., Mackall, J. C., Probst, P. G. \& Chaparas, S. D. (1991). Immunological characterisation of recombinant antigens isolated from a Mycobacterium avium igt11 expression library by using monoclonal antibody probes. Infect Immun 59, 2595-2600.

Sambrook, J., Fritsch, E. F. \& Maniatis, T. (1989). Molecular Cloning: a Laboratory Manual. Cold Spring Harbor, NY: Cold Spring Harbor Laboratory.

Sanger, F., Nicklen, S. \& Coulsen, A. R. (1977). DNA sequencing with chain terminating inhibitors. Proc Natl Acad Sci USA 74, 5463-5467.

Sathish, M., Esser, R. E., Thole, J. E. R. \& Clark-Curtiss, J. E. (1990). Identification and characterisation of antigenic determinants of Mycobacterium leprae that react with antibodies in sera from leprosy patients. Infect Immun 58, 1327-1336.

Scherf, A., Mattei, D. \& Schreiber, M. (1990). Parasite antigens expressed in Escherichia coli. A refined approach for epidemiological analysis. $J$ Immunol Methods 128, 81-87.

Stuart, P. (1965). Vaccination against Johne's disease in cattle exposed to experimental infection. $B r$ Vet J 121, 289-318.

Wieles, B., Van Agterveld, M., Janson, A., Clark-Curtiss, J., Rinke de Wit, T., Harboe, M. \& Thole, J. (1994). Characterisation of a Mycobacterium leprae antigen related to the secreted Mycobacterium tuberculosis protein MPT32. Infect Immun 62, 252-258.

Yanisch-Perron, C., Vieira, J. \& Messing, J. (1985). Improved M13 phage vectors and host strains: nucleotide sequences of $\mathrm{M} 13 \mathrm{mp} 18$ and pUC19 vectors. Gene 33, 103-119.

Young, D. B. \& Mehlert, A. (1989). Serology of mycobacteria: characterisation of antigens recognized by monoclonal antibodies Rev Infect Dis 11(suppl. 2), S431-S435.

Young, R. A., Bloom, B. A., Grosskinsky, C. M., Ivanyi, J., Thomas, D. \& Davis, R. W. (1985). Dissection of Mycobacterium tuberculosis antigens using recombinant DNA. Proc Natl Acad Sci USA 82 , $2583-2587$.

Received 13 December 1993; revised 25 February 1994; accepted 22 March 1994. 